IRSTI 06.77 .61

UDC 331.52

https://doi.org/10.46914/1562-2959-2021-1-1-186-190

\author{
K.Y. IZGUTTIYEVA, $1 *$ \\ $\mathrm{PhD}$ student. \\ *e-mail: kuralaika92@mail.ru \\ L.A. TUSSUPOVA ${ }^{1}$, \\ d.e.s., associate professor. \\ e-mail: 1.tussupova@turan-edu.kz \\ E.M. YERALINA, ${ }^{1}$ \\ $\mathrm{PhD}$. \\ e-mail: e.eralina@turan-edu.kz \\ ${ }^{1}$ Turan University, Kazakhstan, Almaty
}

\title{
THE IMPACT OF THE PANDEMIC ON THE LABOUR MARKET
}

\begin{abstract}
In the context of a pandemic, many enterprises take actions and make specific decisions in conditions of uncertainty, since it is absolutely impossible to predict the development of the pandemic and its possible consequences on the territory of other countries of the world. Thus, business activity also remains in an environment of uncertainty and is subject to a variety of factors that can not only negatively affect certain aspects of their activities, but can also lead to the complete destruction of the business entity. The relevance of the research topic is shown in the identification of the consequences of the coronavirus pandemic and their assessment on the modern labour market. An increasing number of employers' requirements for employees are associated with soft-skills. These include critical thinking, self-management, problem solving, learnability, resilience to stress, flexibility, and etc. The purpose of the study was to assess the current situation in the world and domestic labour market. The object of research was the labour market of the leading countries of the world: the United States, China, great Britain and Canada. The result of the study was the conclusion about further changes in the demand for labour and the conclusion about what the domestic labour market is waiting for in the future.
\end{abstract}

Key words: COVID-19, labour market, crisis, unemployment, income, population, business activity.

With the spread of COVID-19 around the world, it has led to global changes in the economy of not only Kazakhstan, but also other countries. The pandemic affected all countries of the world economy, as a result of which any manipulation in the field of international trade, tourist services and other sectors of the economy was temporarily stopped between individual states. All this certainly affected the development of economic relations between the countries, as well as the unemployment rate and incomes of the population. The purpose of the study was to assess the impact of COVID-19 on the labor market in Kazakhstan and the leading countries of the world. The main objectives of the study were: to assess the level of impact of the pandemic on economic development; assessment of changes in the unemployment rate; assessment of the projected changes in the labor market that will affect it.

The coronavirus pandemic (COVID-19) has spread not only across Kazakhstan, but also all over the world. The spread of a new type of virus originated in China, where a massive infection of the population began in December 2019. As a result, Chinese borders were closed to prevent the spread of a new type of virus, and subsequently international relations between China and other foreign countries were temporarily suspended.

According to the results of the macroeconomic review for the IV quarter of 2020, conducted by $\mathrm{PwC}, 72 \%$ of the surveyed experts believe that Kazakhstan is waiting for a basic scenario of economic development, in which a slow exit from the crisis caused by the COVID-19 pandemic is expected. In general, the uncertainty of the future prospects for economic development is a new reality not only for Kazakhstan, but for the whole world. This is primarily due to the decline in business activity and the need to adapt existing skills, processes and technologies for doing business in the new reality. 
The suspension of international relations had a negative impact on the world economy and the economies of individual countries of the world. The spread of coronavirus infection and ways of dealing with its consequences have also affected the labor market.

For example, quarantine in Kazakhstan made certain adjustments to the structure of employment in Kazakhstan. After the spring lull in the country, the need of personnel has sharply increased, in addition, one can observe the aggravation of the problems of uneven labor resources at the regional level.

Guided by the data of the Labor Resource Center of the Ministry of Labor and Social Protection of the Republic of Kazakhstan, the state electronic exchange enbek.kz observed a monthly decrease in the number of vacancies by $10-26 \%$,

The minimum of offers from employers fell on April - only 25,000 vacant places were offered to Kazakhstanis. This is the first time in the last few years for labor-deficient Kazakhstan. Center analysts associate it with the uncertainty in the economy during the state of emergency in April. The conclusions of the human resources development center shows that the number of technically unemployed (officially employed, but without income) in April this year in Kazakhstan exceeded 4.2 million people. The official statistics on unemployment remained unchanged and amounted to $4.8 \%$.

For the period between 2015 and 2019 the unemployment rate of the Republic of Kazakhstan tended to decrease. So, for the specified period, the overall unemployment rate fell by $1.06 \%$, the level of youth unemployment - by $0.70 \%$.

According to the results of the 2-nd quarter 2020 there was an increase in demand in certain sectors of the economy in Kazakhstan. For example, the construction, transport and industrial sectors became the leaders in the demand for personnel, the share was about $43 \%$ of all vacancies.

In connection with the implementation of projects such as the Employment Roadmap and the increase in the number of construction projects, the need for bricklayers, concrete workers, carpenters has increased. The deficit in personnel was observed in relation to road workers, where the need for personnel increased almost 4 times.

The end of the quarantine and the reopening of most enterprises immediately affected the employment market. The first «working» months reduced the number of technically unemployed to 735 thousand people.

The number of vacancies in the country increased 2.8 times - up to 71 thousand in the period from May till June. This is even more than in the pre-crisis period [1].

In the Russian Federation, in order to prevent the spread of COVID-19, a decision was made at the level of the highest authority to suspend the work of a greater number of enterprises, except for those that are life-supporting (grocery stores and manufacturing enterprises, pharmacies, medical institutions, etc.), part enterprises were redesigned for the production of protective equipment and antiseptics. Thus, the entire April 2020 was declared inoperative.

Today, in some regions of the Russian Federation, the epidemiological situation is critical, and some enterprises do not carry out their activities or carry out it under specific restrictions, i.e. not fully.

The taken measures affected small and medium-sized businesses, since the level of their profitability is several times lower than those of larger economic entities, and such enterprises are not able to cope with expenses in conditions of suspension of activities, incl. to pay employees. As a result, there is an illegal increased pressure on workers to dismiss them of their own free will, and, accordingly, an increase in the unemployment rate [2].In order to confirm the above facts, we will analyze the situation on the world labor market during a pandemic.

In the leading countries of the world, the situation with the unemployment rate has worsened. According to the RIVI website (riwi.com), the latest real-time data collected reflects disappointing data illustrated in Figure 1 (p. 188).

In addition to the growth in unemployment in such leading countries as the United States, Great Britain, China, the income of the population of the above countries is declining. So, in China, the population has lost $45 \%$ of their previous income, the population of Canada - 36\%, the United States $33 \%$ and the UK $-24 \%$ [2].

Thus, we can say that the coronavirus epidemic has not spared any country in the world. Also, we cannot talk about a further deterioration of the current situation, since the problem of eliminating the consequences of the pandemic remains unresolved today. 


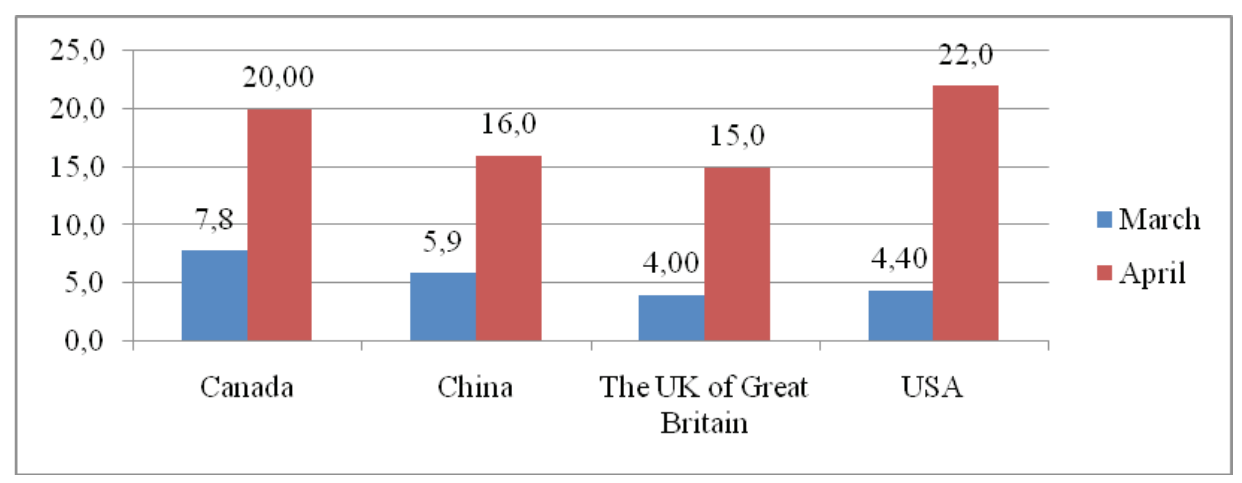

Figure 1 - The unemployment rate in the leading countries of the world as of April 30, 2020, \%

According to experts, further deterioration in the economies of countries is possible, which will directly affect the situation in the modern labor market. At the moment, accurate predictions cannot be made. However, if the situation persists, the countries will face a protracted deep economic crisis.

The data in Figure 1 indicate a high growth rate of the unemployment rate. The highest level of growth in the unemployment rate is observed in the United States (22.0\%) [3].

According to research by the International Labor Organization (ILO), the coronavirus pandemic has had an uneven impact on the labor market for men and women. Thus, the number of women who have been unemployed is greater than that of men; in terms of this figure, this figure is 5 percent for women, and among men -3.9 percent. The pandemic also affected young people (15 to 24 years old), where the unemployment rate was 8.7 percent, while among older people 3.7 percent lost their jobs [4]. Unfortunately, there is still no statistical data for 2020 in the Republic of Kazakhstan on gender employment, but it is possible to analyze the state in terms of gender employment based on the indicators of previous years. As shown in the table below, the unemployment rate for women is higher: 5.4\% in 2017 and 2018, and in 2019 this figure fell slightly to 5.3\%, while the unemployment rate for men is lower [5].

Table 1 - Main indicators of the labor market by months 2017-2019 (estimated data)

\begin{tabular}{|c|c|c|c|c|c|c|c|c|c|}
\hline \multirow{2}{*}{$\begin{array}{l}\text { Main indicators of the labor } \\
\text { market in terms of gender }\end{array}$} & \multicolumn{3}{|c|}{2017} & \multicolumn{3}{|c|}{2018} & \multicolumn{3}{|c|}{2019} \\
\hline & Total & Male & Female & Total & Male & Female & Total & Male & Female \\
\hline Laborforce, thousandpeople & 9027,4 & 4664,2 & 4363,2 & 9138,6 & 4676,8 & 4461,9 & 9221,5 & 4739,7 & 4481,8 \\
\hline $\begin{array}{l}\text { Labor force share in the } \\
\text { population, } \%\end{array}$ & 69,7 & 76,2 & 63,8 & 70,0 & 75,9 & 64,8 & 70,1 & 76,3 & 64,6 \\
\hline $\begin{array}{l}\text { Employedpopul ation, } \\
\text { thousandpeople }\end{array}$ & 8585,2 & 4458,9 & 4126,3 & 8695,0 & 4474,7 & 4220,3 & 8780,8 & 4535,4 & 4245,4 \\
\hline employees, thousandpeople & 6485,9 & 3331,6 & 3154,4 & 6612,5 & 3383,6 & 3228,8 & 6681,6 & 3443,0 & 3238,6 \\
\hline $\begin{array}{l}\text { self-employed, } \\
\text { thousandpeople }\end{array}$ & 2099,2 & 1127,3 & 971,9 & 2082,5 & 1091,1 & 991,5 & 2099,2 & 1092,4 & 1006,8 \\
\hline $\begin{array}{l}\text { Unemployedpop ulation, } \\
\text { thousandpeople }\end{array}$ & 442,3 & 205,3 & 237,0 & 443,6 & 202,1 & 241,6 & 440,7 & 204,3 & 236,3 \\
\hline Unemploymentr ate, $\%$ & 4,9 & 4,4 & 5,4 & 4,9 & 4,3 & 5,4 & 4,8 & 4,3 & 5,3 \\
\hline $\begin{array}{l}\text { Youthunemploy mentrate, \% } \\
(\text { aged 15-24) 1) }\end{array}$ & 3,8 & 3,6 & 4,0 & 3,7 & 3,3 & 4,1 & 3,6 & 3,2 & 4,0 \\
\hline $\begin{array}{l}\text { Youthunemploy mentrate, \% } \\
\text { (aged 15-28) 2) }\end{array}$ & 3,9 & 3,5 & 4,4 & 3,8 & 3,4 & 4,3 & 3,7 & 3,3 & 4,1 \\
\hline
\end{tabular}

While the epidemic continues, there is a demand in the labor market for couriers, salespeople and remote workers. Specialists in certain industries turned out to be unclaimed, for example, this applies to employees in the tourism sector and most of the service enterprises. 
After the end of the epidemic, the demand for specialties that were in high demand in a difficult epidemiological situation will decrease, which is due to a decrease in the need for these categories of workers. Then the demand for workers who were unclaimed during the pandemic will begin to increase.

Changes to which the labor market is subject will depend on the duration of the quarantine measures, as well as the ability of economic entities to increase their production capacity in a short time. The most popular mechanisms in the employment of citizens and the reduction of the unemployment rate will be: retraining and retraining of the population, employment of employees on a part-time basis, etc. Also, after the end of the pandemic, an increase in demand for foreign travel is not excluded, which will contribute to the demand for specialists in the tourism sector, etc. [6].

In general, global trends in the development of the labor market will continue, workers need to think not so much about the consequences of the crisis as about the development of robotization. Certain types of business will not only be able to survive in this situation, but also significantly improve their positions. These types of economic activities include virial (online) entertainment. If there was an increase in this type of service sector before the pandemic, then during a pandemic this growth may be exceeded several times [3].

Summing up the results of the study, we can conclude that the overall result of the end of the pandemic in Kazakhstan and in the world as a whole will lead to a reduction in the number of staff in many companies where they were "bloated". As mentioned above, the demand for specialists who are competent to solve production issues not only at the workplace will increase, but will also be able to quickly transfer their work online. And with the transfer of a significant number of employees to remote work, it will demonstrate that the enterprise does not need to support certain categories of staff members at all. Consequently, despite the measures taken and being implemented to eliminate the consequences caused by the spread of coronavirus in Kazakhstan and foreign countries, it will ultimately lead to an increase in the level of unemployed, a decrease in the income of the population, as well as an economic crisis. However, the severity of all the consequences depends on the duration of the measures implemented by the states. The Government of the Republic of Kazakhstan needs to develop a strategy or action plan, under similar conditions, that will help labor market accept and overcome all the challenges posed by the pandemic. It should also be noted, as analyzed in this article, that the COVID-19 crisis has had an uneven impact on different sectors. Those sectors that are facing the negative effects of the pandemic will recover at a much slower pace. The restoration of these sectors should be aimed at a humane approach, which provides for social support of socially vulnerable segments of society, where the fulcrum will be the person and the observance of his rights.

\section{LIST OF LITERATURE}

1 Official website of the Electronic Labor Exchange of the Republic of Kazakhstan. [Electronic resource] / access mode https://www.enbek.kz/ru (date of treatment 07/27/2020).

2 The pandemic will deprive millions of Russians of sources of income / INDEPENDENT // [Electronic resource] - URL: https://yandex.ru/turbo?text=http\%3A\%2F\%2Fwww.ng.ru\%2 Feconomics\% 2F2020-03-23 \% 2F1_7824_main.html (date of treatment 07/27/2020).

3 Goldfarb D. Profitable truth from COVID-19: losses in real time are worse than they seem [Electronic resource] / access mode https://riwi.com/research/covid-19s-income-truth-real-time-losses-are-worse-thanthey-appear / \# easy-footnote-bottom-2-31087 (date of treatment 07/27/2020).

4 Official website of international labor organizations, report, «COVID-19 and the world of work» https:// www.ilo.org/global/topics/coronavirus/ru/lang--en/index.htm.

5 Official website of the Committee on Statistics of the Republic of Kazakhstan [Electronic resource] / access mode https://stat.gov.kz/ (date of treatment 07/27/2020).

6 Soldatova S.S. (2020). The Russian labor market amid the growing economic crisis due to a pandemic/ S.S. Soldatova, V.V. Soldatova / Scientific and educational magazine for students and teachers «StudNent», No. 2, p. 424-429. 
К.М. ИЗГУТИЕВА, ${ }^{1 *}$

докторант.

*e-mail: kuralaika92@mail.ru

Л.А. ТУСУПОВА, ${ }^{1}$

э.ғ.Д., доцент.

e-mail:1.tussupova@turan-edu.kz

Э.М. ЕРАЛИНА, ${ }^{1}$

$\mathrm{PhD}$.

e-mail: e.eralina@turan-edu.kz

${ }^{1}$ «Тұран» университеті, Қазақстан, Алматы қ.

\title{
ПАНДЕМИЯНЫН ЕНБЕК НАРЫҒЫНА ӘСЕРІ
}

\begin{abstract}
Андатпа
Пандемия жағдайында көптеген кәсіпорындар белгісіздік жағдайында шаралар қабылдайды және нақты шешімдер қабылдайды, өйткені әлемнің басқа елдерінің аумағында пандемияның дамуын және оның ықтимал салдарын болжау мүлдем мүмкін емес. Сонымен, экономикалық қызмет сонымен қатар белгісіздік жағдайында қалады және көптеген факторлардың әсеріне ұшырайды, олар олардың қызметінің кейбір жақтарына кері әсер етіп қана қоймай, сонымен бірге экономикалық субъектінің толық жойылуына әкелуі мүмкін. Зерттеу тақырыбының өзектілігі коронавирустық пандемияның зардаптарын анықтауда және оларды қазіргі еңбек нарығында бағалауда көрінеді. Жұмыс берушілердің қызметкерлерге қоятын талаптарының көбеюі soft-skills-ке байланысты. Оларға сыни тұрғыдан ойлау, өзін-өзі басқару, мәселелерді шешу, үйренуге қабілеттілік, күйзеліске төзімділік, икемділік және т.б. Зерттеудің мақсаты әлемдік және ішкі еңбек нарығындағы ағымдағы жағдайды бағалау болды. Зерттеу нысаны әлемнің жетекші елдерінің: АҚШ, Қытай, Ұлыбритания және Канада еңбек нарығы болды. Зерттеу нәтижесі жұмыс күшіне сұраныстың одан әрі өзгеруі туралы қорытынды және ішкі еңбек нарығын болашақта күтеді деген қорытынды жасады.
\end{abstract}

Тірек сөздер: COVID-19, еңбек нарығы, дағдарыс, жұмыссыздық, табыстар, халық, экономикалық қызмет.

К.М. ИЗГУТИЕВА, ${ }^{1 *}$ докторант.

*e-mail: kuralaika92@mail.ru

Л.А. ТУСУПОВА, ${ }^{1}$

д.э.н., доцент.

e-mail:1.tussupova@turan-edu.kz

Э.М. ЕРАЛИНА,

$\mathrm{PhD}$.

e-mail: e.eralina@turan-edu.kz

${ }^{1}$ Университет «Туран», Казахстан, г. Алматы

\section{ВЛИЯНИЕ ПАНДЕМИИ НА РЫНОК ТРУДА}

\begin{abstract}
Аннотация
В условиях пандемии многие предприятия принимают меры и конкретные решения в условиях неопределенности, поскольку предсказать развитие пандемии и ее возможные последствия на территории других стран мира совершенно невозможно. Хозяйственная деятельность также остается в среде неопределенности и подвержена воздействию множества факторов, которые могут негативно повлиять не только на определенные аспекты их деятельности, но также привести к полному разрушению хозяйствующего субъекта. Актуальность темы исследования проявляется в выявлении последствий пандемии коронавируса и их оценке на современном рынке труда. Все большее количество требований работодателей к сотрудникам связано с softskills. К ним относятся критическое мышление, самоуправление, решение проблем, обучаемость, стрессоустойчивость, гибкость и многое другое. Целью исследования является оценка текущей ситуации на мировом и отечественном рынке труда. Объект исследования - рынок труда ведущих стран мира: США, Китая, Великобритании и Канады. Результатом исследования стал вывод о дальнейших изменениях спроса на рабочую силу и вывод о том, что ждет внутренний рынок труда в будущем.
\end{abstract}

Ключевые слова: COVID-19, рынок труда, кризис, безработица, доходы, население, хозяйственная деятельность. 